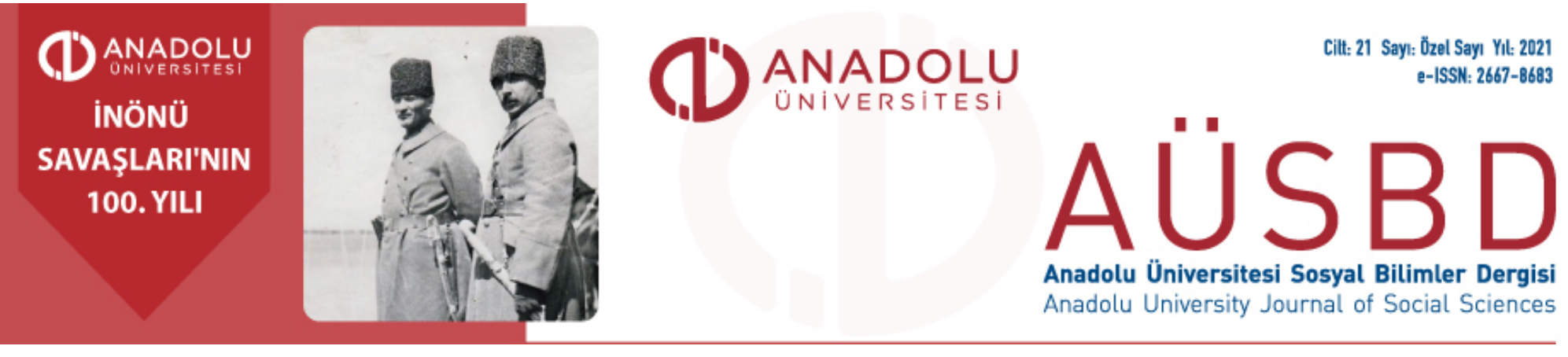

\title{
Maneviyat Maddeye Karşı: Birinci İnönü Zaferi ${ }^{1}$
}

\author{
Ömer OBUZ ${ }^{2}$
}

Başvuru Tarihi: 09.02.2021

Kabul Tarihi: 22.03.2021

Makale Türü: Araştırma Makalesi

\section{Öz}

Birinci İnönü zaferi, Yunan ordusunun direncine vurduğu darbe ve Türk toplumunun ve cephedeki birliklerin morallerini yükseltmesi noktasında çok önemlidir. Bağlantılı olarak da Millî Mücadele’nin başarılacağına olan inancı pekiştirmişsir. Bu gibi yararları doğrultusunda düşünüldü̈̆̈̈nde Birinci İnönü zaferinin Millî Mücadele'deki katkısının son derece kritik olduğu anlaşılır. Bu çalışma Birinci İnönü zaferinin neden önemli olduğunu ve zaferin kamuoyunda nasıl yankılandığını ele almaktadır. Ayrıca bu makalede Birinci İnönü zaferinin, yıllar sonra hangi söylemler ile ele alındığı ve millî kimlik inşasındaki işlevi üzerinde de durulmaktadır.

Anahtar Kelimeler: Birinci İnönü Savaşı, Millî Mücadele, Maneviyat

Atıf: Obuz, Ö. (2021). Maneviyat maddeye karşı: Birinci İnönü Zaferi. Anadolu Üniversitesi Sosyal Bilimler Dergisi, 21(Özel Say1), 145-156.

\footnotetext{
${ }^{1}$ Bu çalışma etik kurul izin belgesi gerektirmemektedir.

${ }^{2}$ Van Yüzüncü Yıl Üniversitesi Edebiyat Fakültesi Tarih Bölümü, omerobuz@yyu.edu.tr, ORCID: 0000-0002-8686-4488
} 


\section{(D) ANADOLU}

iNÖNÜ

SAVAŞLARI'NIN

100. YILI

\section{AÜSBD \\ Anadolu Üniversitesi Sosyal Bilimler Dergisi Anadolu University Journal of Social Sciences}

\title{
Spirituality Versus Materiality: The First İnönü Victory
}

\author{
Ömer OBUZ ${ }^{3}$
}

\begin{abstract}
The First İönü Victory is very important in terms of getting a blow in the resistance of the Greek army and raising the morale of the Turkish nation and the troops on the front. Relatedly, this victory reinforced the belief that the National Struggle will be achieved. Considering such advantages, it is understood that the contribution of the First Inönü Victory in the National Struggle is extremely critical. This study aims to discuss why the First Inönü Victory is significant and how the victory resonates in public opinion. In addition, in this article, it is emphasized the discourses in which the First İnönü Victory was under debate within years after the battle and its function in the construction of national identity.
\end{abstract}

Keywords: The First Battle of İnönü, National Struggle, Spirituality

\footnotetext{
${ }^{3}$ Van Yüzüncü Yıl University Faculty of Letters Department of History, omerobuz@yyu.edu.tr, ORCID: 0000-0002-8686-4488
} 


\section{Giriş}

Hemen ilk etapta söylemem gerekir ki Osmanlı İmparatorluğu'nun uzun yıllar boyunca yaşadığı sorunların içerisinden çıkılamaz bir hâl alması, kaybedilen bir dizi savaş ve artan ekonomik bunalım yöneticilerden yönetilenlere toplumsal tabakaların tamamında ağır bir depresyon ve ümitsizlik yaratmıştı. Bilindiği gibi Osmanlı İmparatorluğu'nu “diriltme, yaşatma, hatta büyütme özlemleriyle” dahil olunan Birinci Dünya Savaş1 sona erdiğinde Osmanlı İmparatorluğu'ndan geriye Türk milleti kaldığına inanan kişilerin sayısı çok azdı (Berkes, 2008, s.475).

Savaşın ardından vatan toprakları işgal edilmiş, ordunun silahları toplattırılmış ve askerleri de terhis edilmişti. Gerçekten de "vatanı koruyacak hiçbir kuvvet kalmamıştı [ve] bir umut sşığı bile” görünmüyordu (Özalp ve Özalp, 1992, s.10). Falih Rıfkı'nın anlatımıyla 1919 yılı; belkide tarih boyunca Türklerin en fazla yalnız, düşmanı en bol, araçsız/silahsız ve en yorgun olduğu zamandı. (Atay, 3 Nisan 1941, s.1). M. Kemal Paşa önderliğinde başlayan Millî Mücadele, doğrusu Türk toplumu için tam anlamıyla bir ölüm-kalım süreciydi. Nitekim bu bilinçle Türkiye'nin her tarafında insanlar işgalleri güçlü bir biçimde kınarken, farklı bölgelerde kanaat önderleri de çektikleri telgraflarla M. Kemal Paşa'nın yanında olduklarını iletiyorlardı (Özteke, 2019, s.340). Yürütülen mitingler, çıkarılan gazeteler ${ }^{4}$ ve diğer bütün propagandalarsa ümitsizliği ortadan kaldırmaya ve millî şuur inşasını sağlamaya dönük motive edici bir kurguya sahipti. Maddi yokluklar zaten inançlı olan Türk toplumunu maneviyat temelinde daha da motive etmiş ve saflar sıkılaştırılmıştı.

Tam da bu aşamada önemli bir parantez kuşkusuz H. Bergson’a açılmalı, zira İmparatorluğun üzerindeki yılgınlık ve moral bozukluğuyla arayışa giren Türk entelektüelleri için Bergson'un fikirleri tabir caizse ilaç gibi gelmişti. Özellikle Dergâh Mecmuası etrafında toplanan genç entelektüeller, onun felsefi anlayışını kendilerine rehber edinmişlerdi. Maddeci Batı'ya karşı maneviyatı öne çıkaran Bergson'un yaklaşımı, anlaşılan o ki kimi entelektüellere yeni bir alan açmış, Millî Mücadele "hayat hamlesi” olarak algılanmıştı (Çınar, 2006, s.86,87). Türk toplumunun hayat hamlesinden anladığı ya istiklaldi ya da ölümün onurlusunu tatmaktı. Diğer bir ifadeyle hayat hamlesi inanç, ruh ve azimden oluşan maneviyat ile ilintiliydi. Maddi olan ise tek başına anlamsız olan silah gibi araç gereçlerdi.

Bilindiği üzere savaşlar, maddi ve manevi güçlerin toplamıyla şekillenir. Yani maddi ve manevi güçler, bir devletin harp gücünü oluşturur. Maddi güç insan ve silah gücünü, manevi güç ise talim ve terbiye, millet, yurt sevgisi, kahramanlık, azim ve kararlılığı gösterirdi. Millî Mücadele’yi değerlendiren pek çok kişi açısından önemli olan maneviyattı. Nitekim savaş tarihi konusunda uzman olan Muallim Hakkı Erdem, hem Çanakkale hem de Millî Mücadele’nin manevi güç sayesinde kazanıldığı söylüyordu (Hakkı Erdem, 1935, s.9-10).

Çanakkale, Birinci İnönü, İkinci İnönü ve diğerleri... Bütün bu zaferler maneviyatla gelmişti, Yakup Kadri Karaosmanoğlu, İkinci İnönü zaferini “ulvi bir hadise”, "asırlarca süren bir uyanış” olarak görürken (Güneş ve Yakut, 2007, s.217) benzer bir üslubu, bir derginin şu cümlelerinde buluyoruz:

“O zaman kırık süngüler birer şimşek, eski tüfekler birer top, toplar birer volkan kesildi. Çünkü, bunların hepsini işleten tarihin derinliklerinden ışık alan Türk ruhu idi. Bu cehennem içerisinde eski dünya bütün cürufu ve enkazı ile çöktü. Adına İnönü zaferi dediğimiz harika doğdu ... Mananın maddeye, hakkın tecavüze, fikrin kör kuvvete galebesidir” (İstanbul Belediye Mecmuası, 30 Nisan 1941, s.226).

Böylesine bir anlayışla donanan pek çok kişiden biri, İ. Hakkı Baltacıoğlu’ydu. O, Anadolu halkının Millî Mücadele’nin heyecanını şuurlu bir şekilde yaşadığını gözlemlediğinden “Anadolu'daki herkesin ruhun muazzam bir hamlesi” olduğunu düşünmüştü (Obuz, 2018, s.85-98). Hatta ona kalırsa Atatürk'ü özel kılan

\footnotetext{
${ }^{4}$ Bu amaçla çıkarılan gazetelerden biri de İrade-i Milliye'dir ve Millî Mücadele'nin kamuoyu olușturma safhasında önemli katkıları olmuștur. Ayrıntılar için bkz. Yunus Özdurğun, "İrade-i Milliye Gazetesinde Millî Hakimiyet Kavramı”, Hakimiyet-i Milliye Uluslararası Bilgi Şöleni, Tam Metin Kitabı, (Editörler: B. Koçlar, M. Pınar, Ö. Karapınar, E. Toprak), 2019, s.375-387.
} 
önemli özelliklerinden biri de hayat felsefesinde gizliydi. Baltacıŏlu’nun ifadelerine göre Atatürk maddi kuvvetlerin geçiciliği karşısında manevi kuvvetlerin bakiliğini idrak etmiş bir hayat felsefesine sahipti, hem zaten Millî Mücadele'nin başarıya ulaşmasını da sağlayan buydu (Obuz, 2019, s.248). Millî Mücadele sürecinde pek çok fedakârlıklarda bulunan Türk toplumu, mananın maddeye galebe çalacağına can-1 gönülden inanmıştı. Nitekim pek çok bedel ödeyerek bu zorlu sürecin sonunda aydınlığa kavuştular. İşte Birinci İnönü zaferi ışı̆̆ın ilk hüzmelerinin görüldüğü yerdi.

\section{Devleti Kuran Savaş: Birinci İnönü}

Türkler açısından 1921 yılının Ocak ayı sıkıntılı başlasa da 11 Ocak, oluşturulan düzenli birliklerin, kumandanlarının ve toplumun kendine olan inançlarının artmasında son derece önemli bir dönüm noktasıydı. Bilindiği üzere Yunanlılar, Bursa'daki üslerinden 6 Ocak 1921 tarihinde İnegöl-Pazarcık yoluyla ilerlemeye başlamıştı. Kızılca kıyametin koptuğu an da Yunanlıların İnönü civarına geldiklerinde karşılarında Türk kuvvetlerini bulmalarıyla yaşandı. Düşman kuvvetleri 9 - 10 Ocak tarihlerinde yaşanan çarpışmalar sonucunda 11 Ocak'ta geri çekilmek zorunda kaldılar (Baykara, 1985, s.93). Atatürk'ün Nutuk'ta ifade ettiği üzere Türk kuvvetlerinin bu zaferi Türk devrim tarihine Birinci İnönü Zaferi olarak kaydedildi (Atatürk, 2002, s.372,373).

Birinci İnönü Savaşı ile birlikte belki Millî Mücadele henüz nihayete ermemişti fakat mevcut koşullar göz önüne alındığında moral-motivasyon açısından büyük bir kıymeti haizdi. Dönemin tanıkları da Birinci İnönü' deki galibiyeti azim, kararlılık, kendine güven gibi işlevleri açısından değerlendirmişler ve bunu büyük zaferin asıl müjdeleyici olarak görmüşlerdi.

Birinci İnönü’ye asıl anlamını veren hususiyet hiç kuşkusuz mutlak bir yoksulluk içerisinde başarılmasıydı. Hem zaten bu savaşın süngülerle, süngünün olmadığı yerlerde taşlarla, yalın ayak, baş açık, ceketsiz, parça parça pantalonlu, vücutları üstlerindeki fişek desteleriyle ısınan askerlerle kazanılmasının bir tek açıklaması vardı ki o da inancın herşeyin üstünde olmasıydı (Bozkurt, 3 Nisan 1941, s.2). Tarafların askeri kabiliyetleri değerlendirildiğinde bu ifade çok daha açık bir biçimde idrak edilir. Bir kaynakta yazılana bakılırsa Birinci İnönü Savaşı’nda Türkler beş bin piyade, elli ağır makineli tüfek, yirmi sekiz top, üç yüz süvariden oluşurken Yunanlılar yirmi bin piyade, yüz elli ağır makineli tüfek, elli toptan ibaretti (Hakkı Erdem, 1935, s.17). ${ }^{5}$

Anlaşılan büyük bir iştahla Eskişehir'i hedef alan Yunanlar, hiç ummadıkları bir sonla karşılaştılar. Aldıkları desteklere ve diğer imkânlarına rağmen Türklerin önünde direnememeleri ve geri çekilmeleri basında da detaylı olarak işlendi. Gazeteler müjdeyi büyük bir gurur ve heyecanla paylaştılar. Misal Vakit gazetesi, 17 Ocak’ta İnönü Meydan Muharebesi başlıklı kısa haberinde zafere şu cümlelerle atıfta bulunuyordu: "Muharebe üç gün üç gece kemal-i şiddetle devam etmiş ve Yunan ordusunun taarruzundan önceki mevziye çekilmesi ile neticelenmiştir" (Vakit, 17 Kanun-1 Sani 1921, s.1). İkdam ise Yunan ordusunun pek fena bir bozguna uğradığını açıklıyordu (İkdam, 18 Kanun-ı Sani 1337, s.1). Bir başkasının ifadelerine bakılırsa bu zaferle Anadolu’nun yüzü gülmüş, savaş bir “darbe-i âhenîn” ile kazanılmıştı (İleri, 17 Kanun-1 Sani 1337, s.1).

Türk kamuoyunun İnönü zaferini kıymetli haklı olarak kıymetli görmüşlerdi. Türklerin galibiyeti TBMM Hükümeti ve düzenli ordusu için zafer ama pek çok imkana sahip olan Yunanlar açısından kendilerine pahalıya patlayan tam bir hüsrandı. (Alemdar, 18 Kanun-1 Sani 1337, s.1). Diğer bir deyişle Yunanlılar açık bir hezimete uğramıştı: "Hakikat şudur ki bugün Bursa cephesindeki Yunan kuvvetleri başlarını önlerine eğerek geldikleri yerlere doğru firar etmektedirler” (İleri, 19 Kanun-1 Sani 1337, s.1). Yunanlıların arkalarında ağır zayiat

\footnotetext{
5 A. Daver’in Matbuat Umum Müdürlüğü’nün 1937’de Fransızca yayınladığı Türk İstiklal Harbi isimli kitaptan aktardığına bakılırsa Türk tarafı 417 subay, 8500 er, 6000 tüfek, 18 hafif makineli tüfek, 47 ağır makineli tüfek, 28 toptan ibaretti. 4000 insan, 850 tüfek, 8 ağır makineli tüfek ve 800 kılıçtan oluşan bir kuvvet de etraftan geliyordu. Yunan kuvvetleriyse 472 subay 15.816 er, 12.500 tüfek, 270 hafif makineli tüfek, 80 ağır makineli tüfek ve 72 toptan oluşuyordu. Bkz. Abidin Daver, “Millî Mücadeleye Aid Hatıralar”, Cumhuriyet, 11 İkinci Kanun 1944, s.2.
} 
bırakarak geri çekilmeleri, Türk toplumu için çok daha büyük bir anlama sahipti. Bu da Mustafa Kemal Paşa'nın İsmet İnönü’ye gönderdiği bir telgraftaki sözlerinden anlaşıllyordu. Yunanlıların püskürtülmesi, istila edilen toprakların düşmandan arındırılması noktasında bir başlangıç olarak görülmüştü (Peyam-ı Sabah, 17 Kanun-1 Sani 1337, s.1).

Bu başarıyla herkeste asıl büyük zafere doğru mutlak bir inanç oluşmuştu. Birinci İnönü başarısı, Türk toplumunu bu inanç etrafında kenetleyebilmişti. Yunanlılara ve destekleyicilerine inancın gücü ekseninde büyük bir gözdağı verilmişti. Her şeyden önce Anadolu, Yunanlılar için yabancı bir toprak parçasıydı. Onlar bir hakikatten yoksun istilacı; Türkler ise milletlerini, istiklallerini, vatanlarını korumaya çalışanlardı. Üstelik bu uğurda can vermeye yemin ettiklerinden karşılarında başarılı olma şansları yoktu (Vakit, 20 Kanun-1 Sani 1337, s.1).

\section{Ardından Söylenenler}

Birinci İnönü zaferinin ardından gelen bir kaç gün içerisinde sıcağı sıcağına yapılan değerlendirmeler, bu başarıdan duyulan haklı gururu yansıtırken düşman karşısında Türklerin manevi açıdan ne kadar teçhiz olmaya başladıklarını ve zafere olan güçlü inançlarını gösteriyordu. Peki bu zafer, aradan geçen yıllar boyunca nasıl anılmış, anılmaya devam etmişti?

Bir kere hemen ertesi yıldan itibaren yıldönümlerinde kutlamalar yapıldığını ifade etmeliyim. Mesela 1922 yılında resmi geçit törenleri, şenlikler, mitingler, alanların süslenmesiyle hatırlandı (Vakit, 11 Kanun-1 Sani 1922 s.1). Şehit ve gaziler unutulmadı, onların kahramanlıklarından bahsedilerek minnet duyguları gösterildi (Hakimiyet-i Milliye, 10 Kanun-1 Sani 1922, s.1). Örneğin Türkiye'nin bir ucunda Van'da, çarşı ve dükkanları halılar ve şallarla süsleyen Vanlılar, zaferi coşkuyla kutlamıştı (Güneş ve Yakut, 2007, s.205).

1920’ler, 30'lar ve 40'l1 y1llarda yerine göre bazen daha sönük ve cansız kimi zaman çok daha coşkulu olsa da esas itibariyle Birinci İnönü zaferi hatırlanmaya, yazarlar, siyasetçiler tarafından çeşitli yönlerden değerlendirilmeye devam etti. Bu zaferi getirenin Türklerin ruhu, inancı, imanı yani maneviyatı olduğuna inanild.

Yeni yeni teşekkül eden millî ordunun bu ilk başarısının manevi kıymetini, maddi öneminden yüz kat daha büyük olduğunu düşünen bir yazarı böyle bir kavrayışa ikna eden yine hiç kuşku yok ki Millî Mücadele'nin başarıyla sonlanacağına yönelik büyük ve son derece önemli motivasyon, bir yazarın ifadesiyle "iman dalgasını" kalplere doldurmasıydı (Daver, 10 İkinci Kanun 1939, s.8). Bir başkası da aynı noktaya temas ederek bunu "imanı zayıf olanların imanını kuvvetlendirdi” şeklinde söylüyordu (A. Rıza, 11 Kanun-1 Sani 1929, s.4).

Dolayısıyla şayet benzer bir durum yaşanacak olursa Birinci İnönü, Türk toplumuna bir örnek, düşmanaysa gözdağı olarak sunulmaya devam etti. Atalarının maddi yokluklar içerisindeyken sinmedikleri, aksine gösterdikleri kahramanlıklar, pek çok kez Birinci İnönü referans gösterilerek anlatıldı. Millî Mücadele’nin içinde yer alan Feridun Dirimtekin, Birinci İnönü’yü bu bakış açısıyla değerlendirenlerden biriydi. Eğer bir gün aynı durumda kalırlarsa yapılması gerekeni geçmişe bakmak ve sadece hatırlamak olarak söylüyordu: “(...) kendimizi de onların çocukları olduğumuzu ve damarlarımızda aynı kanın Fatih ırkının kanının dolaştığını düşünelim. O zaman önümüzde geçilmeyecek mani, ulaşılmayacak bir hedef, kazanılmayacak bir zafer kalmayacaktır." (Cumhuriyet, 10 İkinci Kanun 1944, s.1,3).

Bir gazetede yazdığına göre Eskişehir'i hedef alanların yenilerek çekilmek zorunda kalmaları kuvvetin, çeliğin, vasıtanın değil iradenin, fedakârlığın, kahramanlığın ve Türklerin atalarından miras kalan savaş kudreti ile bilgilerinin zaferiydi (Ulus, 10 Sonkânun 1943, s.1). Peşinen söylemeliyim ki Birinci İnönü zaferi üzerinden 
yıllar yıllar geçmesine rağmen hep aynı çerçeve içerisinde ve birbirine çok benzeyen söylemlerle ele alındı. Türklerin savaş becerileri ve bilgilerine yapılan bu göndermeleri bir kenara alırsak diğerleri ağırlıklı olarak Birinci İnönü zaferini bir şahlanışın, doğuşun ve müjdenin ta kendisi olarak merkeze alması, bağlantılı olarak bu çalışmanın ana eksenini oluşturan maneviyatın maddeye üstünlüğü üzerineydi.

Düşmanın ilerleyişini durduran bu zafer, imkânsızlıkların had safhada olduğu bir atmosferde "doğuş" (Hakimiyet-i Milliye, 10 Kanun-1 Sani 1923, s.1), bazen de zaferin ötesinde olsa olsa "millî bir mucize" idi. Hatta bir yazar İnönü zaferini Bedir Savaşı’na benzeterek Türklerin de bu savaşta "yeni bir imanla" düşmana saldırdığını söylemişti (Birgen, 11 İkinci Kanun 1941, s.1,2). Bir başkasının değerlendirmesiyse son derece mistikti. Nitekim Birinci İnönü’yü, "karnında ilk hayat alametleri beliren yavrusunu ortadan kaldırmak kastıyla kendisine saldıranları diş ve tırnağı ile boğan kahraman ananın şehamet ve azamet dolu gazasına” benzetiyordu (Dincer, 10 İkinci Kanun 1939, s.5). Bu tarz değerlendirmeler, aslına bakılırsa oldukça normaldi. Çünkü daha önce belirttiğim gibi ekonomik durumdan kuvvetlerin eğitimine ve personelin sayısına, silahlardan teçhizata Türk kuvvetlerinin pek çok şeyi noksandı. (İncedayı, Kasım 1991, s.193,194). Bu yüzden genelde benzer noktalarda kümelenen değerlendirmelerin bu zaferin doğuş hatta büyük Türkiye idealinin ilk yaratıcı hamlesi olarak görülmesi son derece anlaşılır (Milliyet, 11 Kanun-1 Sani 1931, s.1).

Verilen bir kaç örnekten de görüleceği üzere Türkler ve Yunanlılar arasındaki mücadele madde ile ruh arasında geçen bir mücadele olarak algılanmıştı. Çelikten bir iman ve irade sergileyen Türk toplumu, maddi gücü ne olursa olsun haksızlığı savunanları yenmiş, yani mana, maddeyi hezimete uğratmıştı. Bu bakış açısı yıllar yılı Birinci İnönü zaferiyle ilgili propagandaların omurgasını oluşturdu.

Cumhuriyet ilan edildikten sonra Birinci İnönü zaferi ile ilgili yapılan değerlendirmelerde bir de Türk kimliğinin yoğun olarak ihya edildiği görülmektedir. Böylece hem olası tehditlere karşı birlik ve beraberliği pekiştirmek hem de millî şuur güçlendirmek istenmişti. Nitekim bir pasajda, Birinci İnönü zaferini, “Türkün damarlarındaki asil kanda mevcut olan kadir-i mutlak kuvvet”in getirdiği belirtilmekteydi (Başbakanlık Cumhuriyet Arşivi, 490.1.0/288-1154-3). Silahı düşmanlarınkine nazaran çok daha az olsa da Türklerin elindeki her silah katbekat değerlendiğinden sayıların hiçbir önemi kalmamış olurdu. Böyle olduğu için de bir avuç asker dünyayı dize getirebilmişti (Talu, 10 Ocak 1946, s.1,3).

Millî Mücadele, özelde de Birinci İnönü zaferinin ardından söylenenler aynı amaca hizmet ediyordu. Bu mücadeleyi Türklerin kendi farkına varması şeklinde okuyanlar olduğu gibi ${ }^{6}$ Birinci İnönü zaferini, Türklerdeki üstün kabiliyetleri gösterdiğinden önemseyenler de vardı. Onlara göre İnönü’deki galibiyeti getiren asli unsurlar dönüşümlü olarak güçlü iman/ruh, asil kan, çelikten irade ya da yüksek savaş kabiliyetiydi. Mesela Siirt Milletvekili Mahmut Soydan için Birinci İnönü'de silahlar değil kalpler, ruhlar çarpışmıştı ve denk olmayan bu güçler arasındaki savaşın galibi Türklerin ruhuydu (Siirt Mebusu Mahmut, 11 Kanun-1 Sani 1930, s.1). Doğrusu Birinci İnönü’nün ardından söylenen her söz Türklerin potansiyeline; kahramanlıklarına, inançlarına, azim ve kararlılıklarına değiniyordu. Tekrar etme pahasına ifade etmeliyim ki bu da maddi yokluklar içerisinde oldukça doğaldı çünkü Türk devriminin bu ilk "temel taşı”, sayıların karşısında azimle, silahların karşısında imanla atılmıştı (Dinçer, 10 Ocak 1947, s.2).

\section{Son Söz}

Metnin içerisinde altını birkaç kez çizdiğim gibi Birinci İnönü zaferinin Millî Mücadele safhasındaki en önde gelen faydası, Türk toplumunun Millî Mücadele’ye olan inancını tahkim etmesiydi. Zira İnönü'de Yunan kuvvetlerinin durdurularak geri çekilmelerinin sağlanması, Türk kuvvetlerine olan güvenci ziyadesiyle

\footnotetext{
${ }^{6}$ Misal Remzi Oğuz Arık, Millî Mücadele ile Türklerin kendilerini bulduğunu, aynı zamanda Türk kimliğine karşı üretilen her ne varsa çürütüldüğünü söylüyordu. Bkz. Mehmet Pınar, Anadoluculuk ve Köycülük Bağlamında Türkiye Köylü Partisi (1952-1958), Libra Kitap, 2020, s.76,77.
} 
artırmıştı, üstelik belki de en gerekli zamanda. Nitekim bu gibi katkılarından ötürü hem gurur duyulan bir başarı oldu ve hem de Türklerin yeniden doğuşunu sembolize etti. Birinci İnönü kurtuluş yolundaki ilk önemli adım olarak görüldü. Ardından geçen yıllar boyunca anılmaya devam eden bu zaferin yıl dönümlerinde düşmanlara gözdağı verildi, öte taraftan Türkler arasındaki birlik ve beraberlik ön plana çıkarıldı. Türk ruhu, inancı ve savaş kabiliyetlerine yapılan vurgularla, haliyle Birinci İnönü zaferi Türk kimliğinin ihyası için de son derece işlevsel olmuştu.

\section{Kaynakça}

A. Rıza. (11 K.Sani 1929). Birinci İnönü, Milliyet, s.4.

Alemdar, (18 Kanun-1 Sani 1337).

Atatürk, M. K. (2002). Nutuk (1919-1927), Ankara: Atatürk Araştırma Merkezi.

Atay, F. R. (3 Nisan 1941). Ylldönümlerini kutlarken, Ulus, s.1.

Başbakanlık Cumhuriyet Arşivi, (490.1.0/288-1154-3).

Baykara, T. (1985). Millî Mücadele, Ankara: Kültür ve Turizm Bakanlığı Yayınları.

Berkes, N. (2008). Türkiye’de çağdaşlaşma, Yayına Hazırlayan: Ahmet Kuyaş, Yapı Kredi Yayınları.

Birgen, M. (11 İkinci Kânun 1941). Birinci İnönünün yıldönümü, Son Posta, s.1,2.

Bozkurt, M. E. (3 Nisan 1941). İki İnönü arasında, Ulus, s.2.

Cumhuriyet, (10 İkinci Kanun 1944).

Çınar, M. (2006). Dergâh dergisi. Modern Türkiye'de siyasi düşünce-muhafazakarlık (5), 85-91.

Daver, A. (10 İkinci Kânun 1939). İnönü zaferimizin yıldönümü, Cumhuriyet, s.1,8

Daver, A. (11 İkinci Kânun 1944). Millî Mücadeleye aid hatıralar, Cumhuriyet, s.2.

Dinçer, C. (10 İkinci Kânun 1939). Birinci İnönü zaferimizin yıldönümünde, Tan, s.5.

Dinçer, C. (10 Ocak 1947). Birinci İnönü, Ulus, s.2.

Erdem, H. (1935). Yunanlılarla İstiklal Harbi, İstanbul: Necmistiklal Matbaası, 1935.

Güneş, İ.ve Yakut K. (2007). Osmanli'dan Cumhuriyet'e Eskişehir (1840-1923), Eskişehir: Anadolu Üniversitesi Yayınları.

Hâkimiyet-i Milliye, (10 Kanun-1 Sani 1922).

Hâkimiyet-i Milliye, (10 Kanun-1 Sani 1923).

İkdam, (18 Kanun-1 Sani 1337).

İleri, (17 Kanun-1 Sani 1337).

İleri, (19 Kanun-1 Sani 1337). 
İncedayı, C. K. (Kasım 1991). Türk istiklâl mücahedesi konferansları (Yayına Hazırlayan Hüsamettin Ünsal), Atatürk Araştırma Merkezi Dergisi, 8(22), 183-231.

İstanbul Belediye Mecmuası, (30 Nisan 1941).

Milliyet, (11 Kanun-1 Sani 1931).

Obuz, Ö. (2018). Türk Rönesansi’nın peşinde bir aydın: Ismayıl Hakkı Baltacıŏ̆lu, İstanbul: Libra Kitap.

Obuz, Ö. (2019). İsmayıl Hakkı Baltacıŏlu’nun bakışından Atatürk, B. Koçlar, K. Yakut, Ö. Obuz. (Editörler), 100. Yılında Millî Mücadele ve Atatürk içinde (s.244-260). Ankara: Cedit Neşriyat.

Özalp, K. ve Özalp, T. (1992). Atatürk’ten anılar, Ankara: Türkiye İş Bankası Kültür Yayınları.

Özdurğun, Y. (2019). İrade-i Milliye gazetesinde millî hakimiyet kavramı, B. Koçlar ve diğerleri (Ed.) Hakimiyet-i Milliye Uluslararası Bilgi Şöleni, Tam Metin Kitabı (s.375-387) içinde. Van.

Özteke, F. (2019). Millî Mücadele'de Güneydoğu Anadolu'da 'kahraman bir belde: Silvan, B. Koçlar, K. Yakut, Ö. Obuz. (Editörler), 100. Yılında Millî Mücadele ve Atatürk içinde (s.329-356), Ankara: Cedit Neşriyat.

Peyam-1 Sabah, (17 Kanun-1 Sani 1337).

[Soydan], Siirt Mebusu Mahmut (11 Kanun-1 Sani 1930). Taliin sesi, Milliyet, 1.

Talu, E. E. (10 Ocak 1946). Şanlı tarih zincirine (...), Son Posta, s.1,3.

Ulus, (10 Sonkânun 1943).

Vakit, (17 Kanun-1 Sani 1921).

Vakit, (20 Kanun-1 Sani 1337).

Vakit, (11 Kanun-1 Sani 1922). 


\section{Ekler}

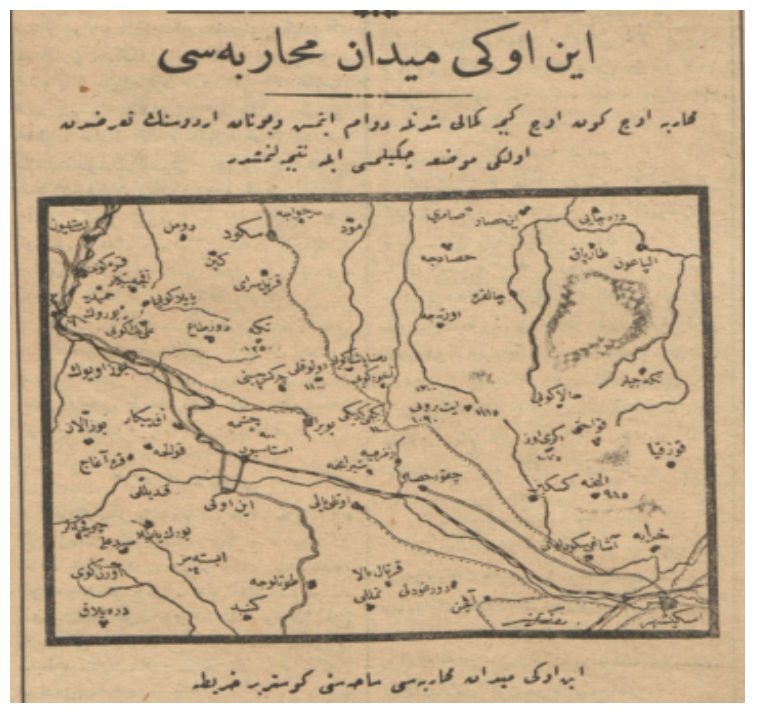

I. İnönü Meydan Muharebesi. Vakit

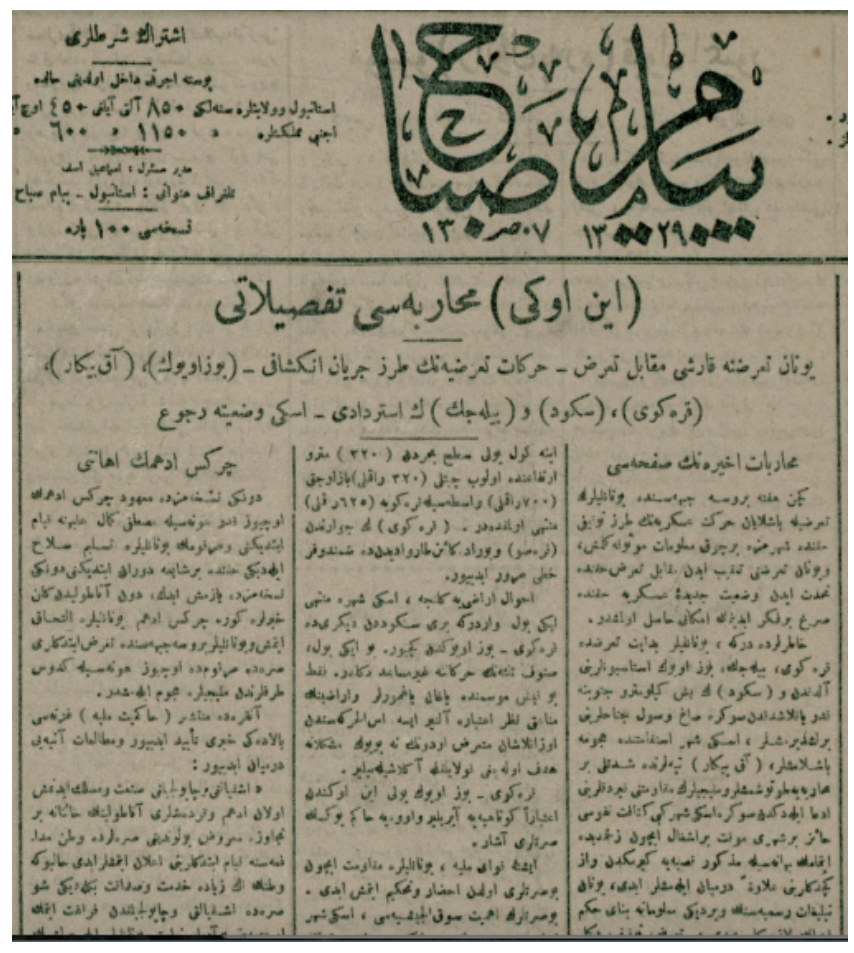

II. İnönü Muharebesi Tafsilatı. Peyam-ı Sabah 


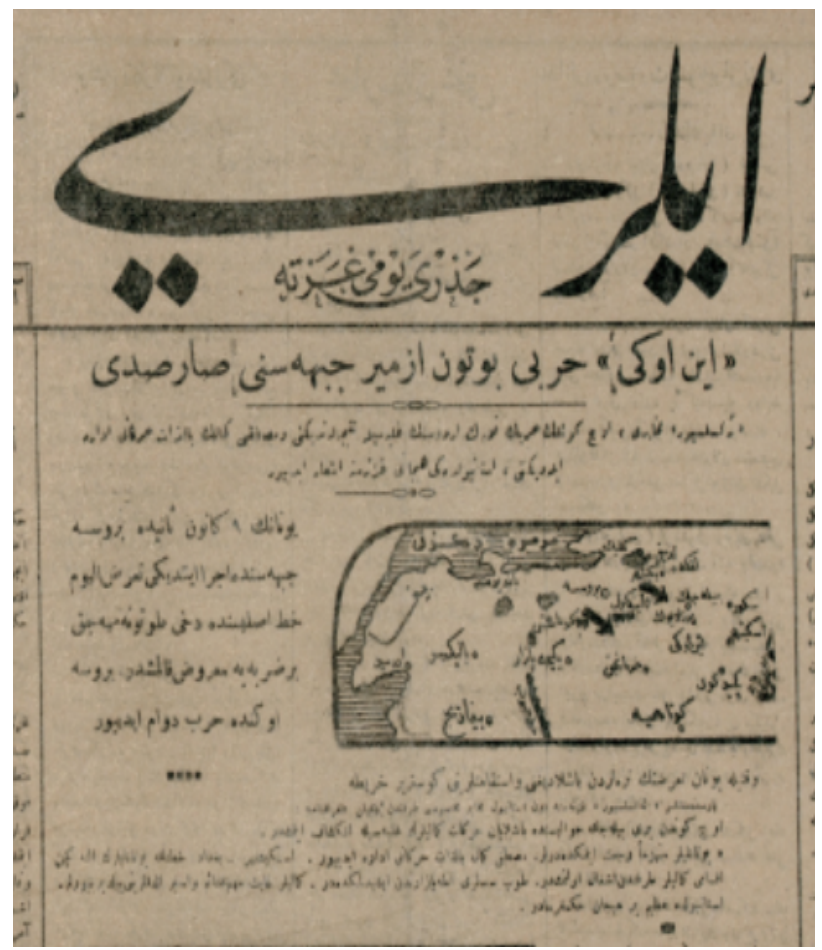

III. İnönü Harbi Bütün İzmir Cephesini Sarstı. İleri

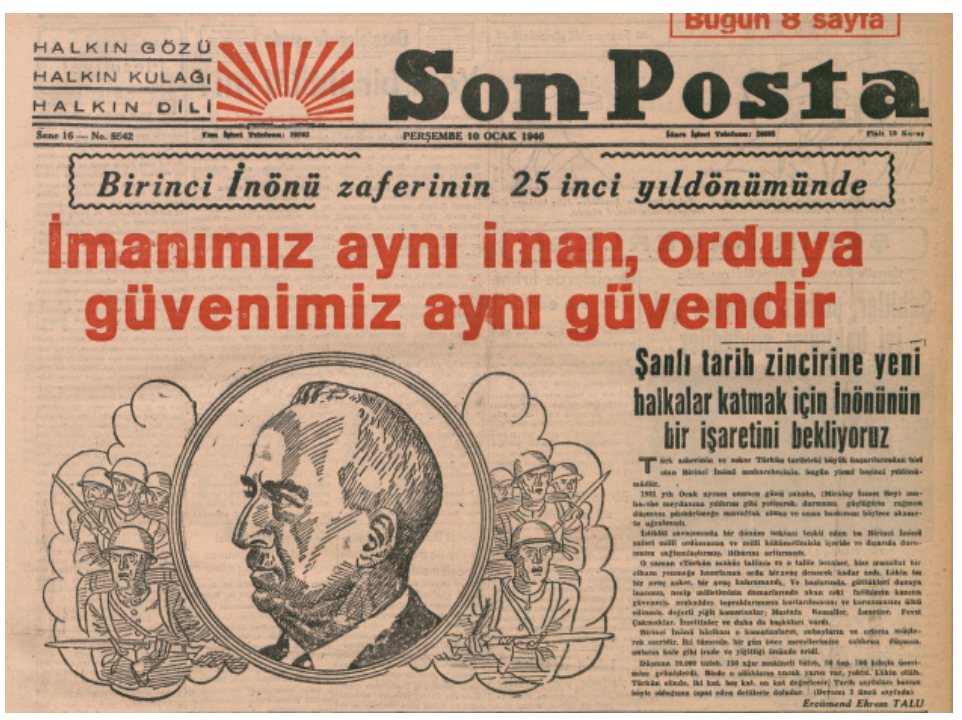

IV. Birinci İnönü Zaferinin 25. Yıldönümünde. Son Posta 


\section{Extended Abstract}

\section{Purpose}

This article focuses on the First Battle of İnönü, which played an extremely important role in the Turkish War of Independence. In this context, it tries to answer the questions of why the battle was important, its function, and how it is evaluated in Turkish public opinion. Considering the conditions in the period when the First Battle of İnönü took place, it will be revealed what kind of evaluations were made regarding the victory. In addition, the study aims to reveal the function of this victory in creating national consciousness by addressing the celebrations and what has been said about the victory in the anniversaries of the First Battle of İnönü after the proclamation of the Republic.

\section{Design and Methodology}

As mentioned above, one of the critical stages of the War of Independence was undoubtedly the First Battle of İnönü. Turkish and Greek troops faced off against each other in January 1921. Greek troops, far superior to the Turks in terms of the number of soldiers and weapons, could not hold on to the Turks and as a result, they had to withdraw on January 11th. Turks achieved a decisive victory in İnönü. The withdrawal of the Greeks in İnönü gave a positive momentum to the National Struggle. The fact that the newly formed Turkish troops stopped the Greek troops despite all the disadvantages, raised the morale of the Turkish society, further united them, and reinforced the belief that the victory would be achieved. This study discusses exactly this process and how this victory is evaluated.

This research was carried out especially by analyzing the data obtained from the periodicals of the period. Therefore, it can be said that the study has a unique aspect in terms of the sources used. In this study, newspapers including Alemdar, İleri, Milliyet, Cumhuriyet, Ulus, and Vakit, which provided important information both after the war and on the anniversaries of the victory, were used. The news and articles obtained from the above-mentioned periodicals were used critically in the relevant parts of the article.

\section{Findings}

As it is known, the Ottoman Empire faced many difficulties that became more intense over the years. The members of the empire made great efforts to save the state from collapse, but despite all efforts, the state could not be prevented from gradually weakening. The First World War was perhaps the last glimmer of hope to save the state, but this war, which was waged with great expectations, was also lost. As a result, imperialist states immediately started to occupy Ottoman lands. Turkish society, under the leadership of M. Kemal Pasha, reacted to these invasions and started a national struggle as a whole.

The First Battle of İnönü was the first step towards the real great victory. Despite all the problems, the newly formed regular troops stopped the Greek advance and pushed them back. Apparently, this victory significantly increased the trust in the Turkish troops, united the society, and greatly increased the belief that the National Struggle would result in victory. The Turkish side did not have enough money, army, weapons, and ammunition. However, there was a great belief that victory would be achieved. As a matter of fact, in Turkish public opinion, the War of Independence and in particular the First Battle of İnönü was discussed as a collision of matter and spirit. Despite all financial difficulties, the Turks were spiritually very strong, and it was this spirit that would bring victory. The public evaluated the Turkish-Greek struggle as the collision between materiality and spirituality. 


\section{Research Limitations}

This article focuses on the First Battle of Inönü in general. The evaluations made both in that period and in the following years regarding this war that took place in 1921 were examined. Especially with the data obtained from periodicals, victory in the First Battle of İnönü was evaluated on behalf of Turks and Greeks, and the discourses after the victory were discussed.

\section{Implications}

Undoubtedly, one of the most important indicators of the First Battle of Inönü, which took place between January 6 and January 11, 1921, is that the Turks won the battle despite various financial difficulties. Hence, this war reflects that belief and spirituality are extremely critical for people and societies. Because the belief and spirit of the Turks also affected those who were hopeless and united the majority of people within the framework of faith in victory. Thus, the First Battle of İnönü with this function, was one of the critical thresholds of the Turkish War of Independence as the masses trusted and supported the Turkish army more as a result of this victory. This research is expected to lead to similar studies.

\section{Originality/ Value}

This study, which examines how the First Battle of İnönü and the ensuing victory resonated, has an original quality. The use of periodicals, one of the most important sources of information of the period, increases the originality of the study.

Araştırmacı Katkısı: Ömer OBUZ (\%100). 